\begin{tabular}{ccc}
\hline & International Journal of Engineering \& Technology, $7(2.13)(2018) 71-74$ \\
SPC & International Journal of Engineering \& Technology \\
Website: $w w w . s c i e n c e p u b c o . c o m / i n d e x . p h p / I J E T$ & Research Paper \\
\hline
\end{tabular}

\title{
Practices of solidarity as a subject of intellectual traditions in Russia and the west
}

\author{
Vitaliy V. Kovalev*, Yuriy G. Volkov, Anatoly V. Lubsky, Natalya K. Bineeva, Nona Z.Gubnelova \\ Southern federal university \\ *Corresponding author E-mail: vitkovalev71@gmail.com
}

\begin{abstract}
This article attempts to make a comparative analysis of the assessment of solidarity practices in the intellectual tradition in Russia and the West. In the foreign intellectual tradition, four paradigms are highlighted in the study of solidarity practices: sociological, philosophical, ideological and religious. The Russian intellectual tradition includes religious and ideological paradigms. In the West, sociology and philosophies have played a major role in the study of solidarity practices, in which scientific knowledge or normative knowledge has been developed and used to put social reality under control. In the Russian intellectual tradition, practices of solidarity have been given a moral or axiological dimension.
\end{abstract}

Keywords: Practices of Solidarity; Solidarity; Paradigm; Intellectual Tradition; Sobornost; Modernization; Solidarism; Stability; Corporate State; Religion.

\section{Introduction}

Cross-cultural studies conducted by G. Hofstede and his followers show that the values of solidarity prevail in Russia and the Nordic countries, while in western countries such as the United Kingdom, the USA, Ireland, Germany, Austria, Italy and Switzerland, there is an overriding aspiration to personal achievement. These aspirations are less pronounced in France and Spain. However, the emergence of civil communities in the West was accompanied by the emergence of not only citizenship implying that "everyone must be involved in issues of life in society and to act throughout his life as an active and responsible citizen, respecting the rights of others", but also the various repertoires of solidarity practices, underlining the importance of transpersonal preferences.

The idea of solidarity, well established in the public consciousness of Europeans, has penetrated wide currents of social thought, including sociology as a science of society. In doing so, researchers note that "interpretation of the idea of solidarity has been as varied as these currents; moreover, they have often fought together strongly. Many adherents of certain varieties of solidarism, from 19 th to the present day, are active in different European countries, including, of course, Russia".

It must be noted, however, that the fate of the idea of solidarity was extremely complex: the periods of rising and declining interest in it have constantly succeeded each other, the notion of solidarity has been marginalized, disappeared, and then appeared in intellectual discourse again. At present, there is an increasing interest in solidarity, which is sometimes "interpreted as a concentrated expression and (or) synonymous with social life", or as a boundary concept on the fringes of science, morality, law or politics".

By the end of 20th century, the idea of solidarity has begun to take shape that allowed the solidarism to be seen as the third way of Europe to overcome the extremes of individualism and collectivism. Therefore, the cumulative concept of social solidarity, developed in the form of the late modern, is particularly popular today including the notions that, first, "a description of solidarity in terms of interpersonal (inter-subjective) relations means the recognition of the individual in question as an equal and worthy partner of interaction", secondly, "a society that can be described in terms of solidarity is based on a fair distribution of the chances of its subjects for recognition", thirdly, "a just order of recognition is a prerequisite for social cohesion and solidarity".

In the Russian intellectual tradition, particular importance was atached to the human dimension of solidarity in the context of spiritualization of sociality, rather than to the social dimension. As S.A. Levitskiy noted, "the source of solidarity is not an impersonal public nature, but the free solidarization of the kingdom of individuals". Speaking in 2013 at the opening of the 17th world Russian People's Council, on the theme "Russia as a country-civilization. Solidarity society and the future of the Russian people", the Patriarch of the Russian Orthodox Church, Kirill, proposed the concept of Russia as a country-civilization. Noting that "the value of any civilization is what it brings to humanity", he stressed, "Russia, as a countrycivilization, has something to offer to the world", in particular the idea of human solidarity, permeating "our history and culture over many centuries".

Thus, solidarity as an idea and solidarity practices as a special kind of social interaction are the subject of sufficiently long intellectual traditions in Russia and the West. The scientific understanding of this tradition makes it possible to better understand the cultural and epistemological contexts and peculiarities of the interpretation of solidarity practices in both Russian and foreign discourses.

\section{Review of scientific literature}

In the context of globalization, there has been an increased cognitive interest in solidaristic practices aimed at consolidating local communities [1]. As a result, the number of scientific publications on various aspects of solidarity and solidaristic practices is con- 
stantly increasing. In the scientific literature, some research has already been done on this subject, particularly within such disciplines as philosophy, sociology, political science and psychology. At the same time, researchers point out that philosophers focus on social solidarity as a moral value, a resource for the interaction of individuals, the basis of public order and the result of political initiative of the authorities [2], [3]. In addition, the issue of solidarity was particularly popular in Russian society in the context of its historical grounds [4].

In the literature, the ideas of liberalism, socialism and solidarism, as well as the representatives of French, German and Russian solidarism and their relationship with philosophical national traditions, have already been analysed in a comparative way. Comparing the ideas of solidarism in Russia and in the west, researchers have drawn attention to the fact that solidarism "remains faithful" to Russian and Orthodox traditions, and its spiritual homeland in the cultural slavophilism, "whose representatives were inspired by the idea of organic solidarity, which, in religious and social terms, means "sobornost"and in socio-political - "solidarity"". Some researchers have compared the views of the representatives of German solidarism and Russian solidarism, expressed in the ideology of the $\mathrm{Na}-$ tional Alliance of Russian Solidarists, within the framework of natural solidarity [5], [6].

The special sociological works contain fragments, summarizing the views of the classics of sociological thought as well as of modern foreign sociologists who have studied the problems of solidarity in modern society. In doing so, researchers have pointed out that sociologists have traditionally attracted such issues as social solidarity and social regulation, social solidarity and social identity, forms and types of social solidarity, characteristics of solidarity practices in complex societies.

Showing the peculiarities of political research, the authors noted that the focus of scholarly attention was primarily on the role of solidarity in political life; the political and legal aspect of the liberal tradition of solidarity, justice, equality and freedom; modern western concepts of political solidarity; political solidarity as a factor in the political process of today's Russia. In doing so, some researchers have stressed that insufficient attention has been given in Russian political science in identifying the instrumental meaning of civic solidarity in the sphere of public policy; the problems of solidarity, political integration and civil society remain insufficiently studied; the question of the historical reasons of solidarity in political life also remains debatable. The authors draw attention to the focus of psychologists on issues of direct relevance to social solidarity, such as social cohesion, group unity and social order, trust, participation, integration and cooperation, empathy, sympathy and altruism [8-10].

The outcome of the study of social solidarity in individual scientific disciplines suggests that contemporary scientific research practices address a wide variety of aspects in contemporary society and in historical retrospect. The study also focused on the history and features of solidarism in various countries, including Russia. However, the comparative aspect of the study of solidarity practices as a subject of Russian and foreign intellectual traditions has not yet attracted the particular attention of researchers.

\section{Methodology}

Intellectual traditions can be based on theoretical principles of in tellectual history, which are broadly interpreted as the history of mentalities and the history of ideas considered in a broad cultural context. In a narrow sense, intellectual history is a history of ideas, involving an understanding of how "new beliefs and intellectual forms are emerging and spreading, coverage of psychological nature of processes affecting changes in the popularity and influence of ideas, discovering, if possible, how concepts that dominated or prevailed in one generation lose their power over the minds of people and give way to others". Therefore, in the framework of intellectual history, the tradition is interpreted as a prerequisite for intel- lectual activity, as its derivative, and as a form and way of preserving the intellectual heritage. At the same time, "intellectual tradition is seen not only as the succession of ideas and modes of thinking, the continuity of historical inheritance in the intellectual sphere, but as a process of reinventing, actively perceiving, selection, reformatting, creative transformation, overcoming or reviving".

At present, the study of intellectual traditions implies, on the one hand, the identification of the content of the ideas themselves and, on the other hand, the establishment of their paradigmatic basis, which are considered in cultural and epistemological contexts. In this regard, special attention is given to intellectual communities acting as creators, custodians, interpreters and translators of an intellectual tradition. Thus, the study of intellectual traditions is inextricably linked to the history of formal and informal intellectual communities, including scientific ones.

The methodological basis for studying solidarity practices as a subject of intellectual traditions in Russia and the West, which, on the one hand, is cognitive field of the continuity of ideas in the intellectual communities, but also a space of intellectual struggle in social sciences, is the principles of historical and scientific research. In a broad sense, the subject of historical and scientific research is the history of ideas, the history of people as creators of science, and its history as a social institution. In a narrow sense, the subject of historical and scientific research is the development of science as a system of knowledge, that is, the content of scientific concepts and their paradigmatic basis.

In this understanding of the subject of historical and scientific research, theoretical reflection of the established thematic areas in the scientific study of solidarity practices, their paradigmatic basis and the results obtained from various disciplinary practices is of particular importance. The basis for this reflection is a critical epistemological analysis of the existing scientific knowledge system on solidarity issues. This analysis involves the following methodological procedures: first, identification of subject fields of disciplinary research practices and identification of their paradigmatic basis; secondly, description of the scientific results, definition of discussion issues and the scientific gaps; third, establishing the authenticity (validity and completeness) of scientific knowledge by assessing their justification, identifying contradictions and scientific gaps in the existing knowledge system.

\section{Results of the study}

In the foreign intellectual tradition, sociological, philosophical, ideological and religious paradigms can be distinguished in the study of solidarity practices. The study of solidarity within the sociological paradigm is a long-standing tradition. At the same time, some researchers point out that, in a sense, sociology began as a study of social solidarity. The founder of sociology A. Comte viewed solidarity as a universal property of all natural phenomenon, manifested in the presence of synchronic and diachronic links between elements of the whole and in the form of consensus in society, interconnecting generations through tradition.

G. Spencer sought to identify the laws of solidarity in society, special attention to social solidarity has been paid by E. Durkheim who justified the idea of two types of solidarity in society: mechanical and organic. The further development of sociology in the 20th century could not, to varying degrees, ignore the analysis of solidarity and solidaristic practices. In fact, this interest is determined by the object of the science itself, a society that has been studied by any sociologist from the perspective to discover systemic links of an integrative nature. To a broad sense, this relates to structural functionalism, social interactionist theory, social exchange theory and constructivist structuralism.

The qualitative transformation of the notions of solidarity according to the intellectual tradition in the west occurred at the turn of 1920th centuries within the philosophical paradigm combining academic interest with socio-political biases. As a result, solidarity has come to be seen as a desirable moral construction based on the scientific knowledge of the actual social processes and, at the same 
time, "plotting" solidaristic practices as a means of influencing these processes.

Representatives of the philosophical paradigm, integrating ideas of the philosophy of law and social economy, suggested a syncretic concept of solidarism that reflected not only the real but also desired state of solidarity and solidarity practices in society. In particular, solidarism in France in the late 19th - the early 20th centuries became a powerful social movement. As an official philosophy, solidarism, as the researchers point out, was one of the main ideological symbols of the Third Republic, aimed on the one hand against nationalism, monarchism and clericalism, on the other, against revolutionary Marxism.

L. Bourgeois has made a special contribution to the development of solidarity ideas within the philosophy of law. Based on the theory of "quasi-social contract" between free individuals, he believed that the law of solidarity in society was universal. It results mutual obligations and cooperation between the various layers, the contract between society and the State, its coordinating role, and the rights and duties of individuals in relation to each other, to their contemporaries, ancestors and descendants. In so doing, he sought to combine the moral and scientific aspects of the idea of solidarity by deriving the first aspect of the latter.

In the second half of 20th century, solidarism has gradually begun to close with the political practice of social democracy, which was made possible by the refusal in the 60-70-s by its representatives from Marxism and its class struggle. Most consistently, this was done in the Scandinavian countries, where the models of a socially oriented state, known as "Swedish socialism", were built.

In general, it should be noted that solidarity ideas conceptually made in France at the beginning of 20th century, have had a great impact on specific social practices in Western European countries, on the one hand justifying the need for an active social policy on the part of the state, on the other, forming social responsibility as a normal practice of human interaction.

However, in some countries of Western Europe, in the second quarter of 20th there was an experience of solidarity practices in which the Italian fascists adopted the ideas of solidarism. In this regard, specific practices of solidarity in fascist political movements and regimes deserve separate attention within the ideological paradigm of solidarity.

At the time, one of the intellectual leaders of the European solidarism was V. Pareto, the creator of the corporate Theory of society. V. Pareto believed that people joined into social groups based on corporate interests. The arbitrator in relations within and between corporations is the state, ensuring social harmony in society. Therefore, the fundamental principle of the corporate state proclaimed solidarity as an idea to serve the state. The ideas of V. Pareto were adopted by the young Italian fascism, so his leader B. Mussolini constantly referred to solidarity as the foundation of his system of corporate state.

Within the religious paradigm, a special place in the history of solidarity ideas belongs to G. Gundlach, who developed the concept of solidarism in the context of the social doctrine of Christianity. The religious understanding of solidarity within the socially responsible market economy model was proposed. von Nell-Bruning proposed the conceptual design of Christian solidarism in his works. In his understanding, solidarism manifests itself in the highest form of cooperation and interaction among people, where reflexive choice of mutual benefit and the internal understanding of human unity as manifestations of divine plan determine the self-organization and order.

Religious and ideological paradigms can be distinguished in the study of solidarity practices in the Russian intellectual tradition. Within the framework of the religious paradigm, solidarity practices were considered in the context of comprehending the divine purpose of the Russian people and gaining civilizational identity. Within the ideological paradigm, it was considered in the context of addressing the challenges of modernization development as a way of overcoming the various forms of civilizational underdevelopment in Russian society.
The concept of sobornost in solidarity has emerged within the framework of the religious paradigm in the 19th century, in which three directions can be distinguished. The representatives of one of them viewed sobornost in solidarity as a Christian existential ideal that can be achieved in the future on the basis of the ethical norms common to all the Christian peoples, because of the gradual moral development of humankind. The leading representative of this field was V.S. Solovyev, whose concept of sobornost is based on church unity and Christian morality, which he has derived from the principle of reasonable and moral necessity, informed by free choice. According to S.L. Frank, sobornost is based on spiritual unity, religion and common destiny. Sobornost in solidarity, as noted by N.A. Berdyaev, is based on a religious consciousness that corresponds to the highest level of spiritual development.

From the point of view of the second direction, sobornost exists in the form of a Christian existential ideal, which can emerge exclusively in Russia as an orthodox country, but only with the reform of the Orthodox Church and the public institutions contributing to the churching of believers. At the same time, A.S. Khomyakov considers the unity of collectivity and freedom avowed the moral law of Christian love as a basis for sobornost. L.P. Karsavin believes that sobornost is a theocracy, churchy world, with high morals and the love of Christ.

Representatives of the third direction, who believe that the basic principles of sobornost in Russia have already prevailed, are united by sacral attitude to the Russian national traditions. This relationship is based on the notion that the traditional life of the Russian people is more fully reflects the specificity of Christian thinking and behaviour. For example, for K.S. Aksakov, sobornost is the result of organic synthesis between orthodox values and Russian traditions. That is why the Russian people preserved the spirit of religion, managed to avoid a rational attitude to the world and, as a consequence, secularization of public life. In this sense, sobornost in solidarity is linked not only with the Orthodoxy, but also with the natural characteristics of the Russians.

In the Russian intellectual tradition, various concepts of solidarity practices of a socialist nature, represented in the ideologies of Narodniks, Anarchists and Marxists have been particularly popular. In the ideology of Narodniks and Anarchists (P. Kropotkin) solidarity was seen as a means of realizing universal equality and prosperity as an essential factor in the development of human society, the loss of which leads to mutual struggle for existence, poverty and exploitation. At the same time, M.A. Bakunin, while considering its essential link with freedom, by solidarity meant reconciling the material and public interests of the individual with human responsibilities. Under the solidarity Lavrov also understood "the knowledge that personal interest coincides with the public interest" and "that personal dignity depends on supporting dignity of all people who are solidarity with us". Representatives of this thought, which was institutionally set up in emigration in the late 1920s as the National Alliance of Russian Solidarists, have criticized liberal, fascist and communist practices of solidarity. On the basis of the synthesis of Russian religious philosophies and western European social reformations, the representatives of this "Alliance" have established the ideology of reorganizing society on the principles of solidarity based on personal freedom, social control, and social justice, a component of which is the use of property for the benefit of all citizens.

\section{Summary}

In the foreign intellectual tradition, four paradigms can be highlighted in the study of solidarity practices: sociological, philosophical, ideological and religious. Within the sociological paradigm, social solidarity has been examined from the perspective of the actual solidarity practices that are the basis of integration in a society that provides its stability. Within the philosophical paradigm, solidarity was focused on intent as a moral construction derived from scientific knowledge of social processes. Within the ideological paradigm of solidarity as an idea of service to the corporate state, the specific solidarity practices of fascist political regimes deserve 
attention. Within the religious paradigm, the Christian idea of solidarism is the highest form of self-organization and manifestation of divine plan.

Religious and ideological paradigms can be distinguished in the study of solidarity practices in the Russian intellectual tradition. Within the religious paradigm in which solidarity practices were considered to understand the divine purpose of the Russian people, the concepts of sobornost as a Christian or orthodox existential of ideal or social reality were developed from a synthesis between orthodox values and Russian traditions. Within the ideological paradigm, liberal and socialist interpretations of solidarity practices can be distinguished. The liberal interpretations of solidarity practices, which are based on a free individual, are confined to the idea of civil society and the development of a sustainable horizontal relationship based on the harmonization of group and individual interests. In the socialist interpretations of the solidarity practices contained in the ideological representations of the Narodniks, Anarchists and Marxists, they were seen as a means of achieving universal equality and prosperity through harmonization of public and individual interests. The Marxist interpretation of the solidarity practices includes the concept of class solidarity as a basis for collective action by the proletariat in the fight against the bourgeoisie, as well as for the international mutual assistance of workers. Within the framework of the ideological paradigm, it is possible to highlight the idea, representatives of which, in an effort to overcome the extremes of liberal, socialist and Marxist interpretations of social solidarity, believed that the foundation of solidarity were the principles of individual liberty, social control and social justice.

A comparative analysis of foreign and Russian intellectual traditions in understanding solidarity practices leads to the conclusion that in the West, sociology and philosophies have played a major role in the study of solidarity practices, in which scientific or normative knowledge has been developed to put social reality under control. In the Russian intellectual tradition, the religious and ideological paradigms have played a major role in the interpretation of solidarity practices. However, unlike the religious paradigm in a foreign intellectual tradition in which the social and political dimension was attached to solidarity practices, in the Russian intellectual tradition, practices of solidarity have been given a moral or axiological dimension.

\section{Acknowledgement}

The article is written within the framework of State Mission (Ministry of Education and Science of the Russian Federation), project № 28.3486.2017/ PCh "Civil patriotism in the formation and development of solidarity practices in the Southof Russia: resource potential and conditions for its utilization".

\section{References}

[1] The article is written within the framework of State Mission (Ministry of Education and Science of the Russian Federation), project № 28.3486.2017/ PCh "Civil patriotism in the formation and development of solidarity practices in the Southof Russia: resource potential and conditions for its utilization".

[2] Hofstede G. National cultures in four dimensions. A Research-based Theory of Cultural Differences among Nations // International Studies of Management \& Organization. 1983. Vol. XIII. N 1-2. P. 60 Dubitskaya V.P., Tararukhina M.I. Byt li Rossii Amerikoy? Rossiyskoye issledovaniye upravlencheskoy kultury po metodike Geert Hofstede // Sociological journal. 2010. № 4. P. 44-45.

[3] European Year of Citizenship through Education. 2005. Learning and living democracy. Concept Paper. Ad Hoc Committee of Experts for the European Year of Citizenship through Education (CAHCIT) // Council of Europe. Strasbourg, 29 November 2004. [Electronic resource]. URL: http://www.nefmi.gov.hu/letolt/nemzet/eu/Concept $\% 20$ paper $\% 20$ for $\% 20$ the $\% 20$ European\%20Year\%20of\%20Citizenship\%20through\%20Education.pdf.

[4] Dean J. Solidarity of strangers. Berkeley: University of California press, 1996.

[5] Social Solidarity // New Connections to Classical and Contemporary. Social Theory: Re-wiered. [Electronic resource]. URL: http://routledgesoc.com/category/profile-tags/social-solidarity.

[6] Gofman A.B. Solidarnost ili pravila, Durkheim ili Hayek? O dvukh formakh sotsialnoy integratsii // Sociological yearbook. 2012: Collection of scientific works / ed. by N.E. Pokrovsky, D.V. Yefremenko. Moscow: INION RAN; Department of General Sociology NRU HSE, 2013. P. 100

[7] Blais M.-C. La solidarité: Histoire d'une idée. P.: Gallimard, 2007.

[8] Gofman A.B. Solidarnost ili pravila, Durkheim ili Hayek? O dvukh formakh sotsialnoy integratsii. P. 107

[9] Sendrov V.A. Solidarizm - tretiy put Yevropy // Portret solidarizma: Idei i lyudi / Sost. V.A. Senderov. Moscow: Posev, 2007. P. 302-303.

[10] Juul S. Solidarity and social cohesion in late modernity: A question of recognition, justice and judgment in situation // European journal of social theory. London, 2010. Vol. 13. N two. P. 253-269. 